\title{
The Identification of Modeling Causes of Stunting Children Aged 2-5 Years in Aceh Province, Indonesia (Data Analysis of Nutritional Status Monitoring 2015)
}

\author{
Bustami Bustami $^{1 *}$, Miko Ampera $^{2}$ \\ ${ }^{1}$ Department of Nursing, Ministry of Health Polytechnic of Meulaboh, Aceh, Indonesia; ${ }^{2}$ Department of Community Nutrition, \\ Polytechnic of Health, Ministry of Health, Aceh, Indonesia
}

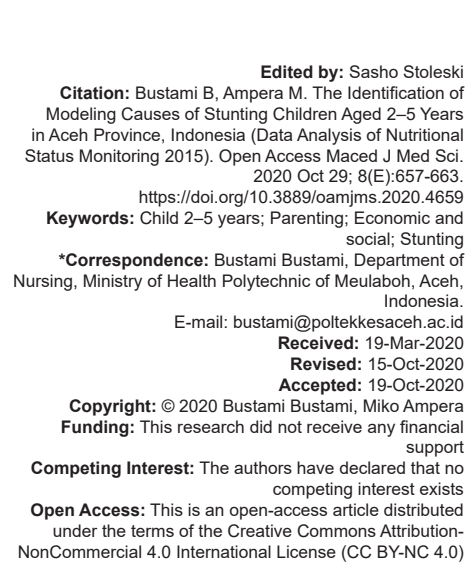

\section{Introduction}

The success of a nation's development is determined by the availability of quality human resources (HR). The quality of HR of a nation can be seen from the human development index. Based on UNDP, the Indonesian human development index is categorized in the medium of human development with the position of 124 out of 187 countries, still below other ASEAN countries [1]. One determinant of the quality of $H R$ is the level of health and nutritional status [2]. The healthier the condition of a community, the more it will support economic development and the level of productivity of an area [3]. Stunting can be caused by direct and indirect causes. The direct causes of stunting are inadequate food intake and infectious diseases, while indirect causes of stunting include food insecurity, inadequate feeding and care practices, poor environmental health, and poor health services [4].

Stunting deals with various adverse and permanent impacts. The impact of stunting can be in the form of increased morbidity and mortality, decreased child development, height is not optimal as an adult, the risk of obesity and non-communicable diseases, as well as decreased capacity for learning achievement, work capacity, and productivity [5]. Stunting reflects that children get inadequate food intake in a long time, so it cannot support normal growth [6]. Strong food intake is related to children's eating habits. However, early childhood eating habits are still completely dependent on food provided by parents [7]. Stunting in developing countries occurs when children are under- 5 years old, factors that cause stunting in children are caused by three things: Nutrient intake, infectious diseases, and interactions of mothers and children, all of which are largely determined by socioeconomic conditions and level of education in the family. Some of the causes of stunting in infancy, in developing countries, the main factors are inadequate food intake, infection, and weight at birth [8].

Stunting starts from the uterus and continues after birth so that nutrition and maternal health during pregnancy has a role in the occurrence of stunting in children [9]. Although nationally the prevalence of nutrition problems has decreased, there are still 18 
provinces above the national prevalence, and Aceh Province is among the top 10 with nutritional problems. The prevalence of stunting problems in children underfive in 2015 is still provincial by $31.6 \%$. There was a decrease in stunting in Aceh from 2013 (Riskesdas $2013=41.5 \%$ ) which was $5.4 \%$, wherein 2013, the prevalence of stunting in Aceh was above the national prevalence (Indonesia $=37.2 \%)$. There are 11 districts that have a prevalence of stunting problems above the provincial figure. To reduce the impact of stunting in the future, it is necessary to know the causes of stunting in children under-five in Aceh Province so that the right steps for conducting intervention activities are identified as priority scale. Therefore, it is necessary to conduct an in-depth study and analysis to analyze and identify models of factors causing stunting of children aged 2-5 years in Aceh Province based on the results of a 2015 Nutrition Status Monitoring (PSG) survey in Aceh.

\section{Methods}

This research used quantitative methods with cross-sectional study design and analytic descriptive. This research was conducted from April to October 2019 in 23 cities/regencies in Aceh Province. The population was that all households had toddlers aged 24-59 months. The method of determining the sample was done by probability sampling with a cluster sampling technique. Determination of the sample was done in two stages, namely, (1) first selecting a cluster for each district and city and (2) the second chooses the household sample in each cluster. Each district and city was selected 30 clusters. Data collection was carried out with a literature study, survey, and Nutrition Status Monitoring obtained at each health office in 23 cities/ regencies within the Province of Aceh. Data processing through the process of editing, coding, entry, cleaning data entry was performed using Predictive Analytics Software.

Data analysis began with descriptive analysis which was describing objects through data in the sample studied based on variability. The statistical test used was the distribution of frequency, minimum, maximum, mean, and deviation. Bivariate analysis was performed to measure the relationship between independent and dependent variables. To strengthen the results of this analysis, the linear regression test was used which aimed to prove the hypothesis proposed with $\mathrm{Cl}$ : $95 \%$. The results of the bivariate analysis, followed by analyzing the data in a multivariate manner, were carried out specifically to find out which of the independent variables had the most role in relation to the dependent variable (stunting). Statistical tests for multivariate analysis used the multiple logistic regression test $(\mathrm{Cl}$ : 95\%).

\section{Results}

\section{Modeling causes of stunting}

Bivariate analysis using Chi-square test on $\mathrm{Cl}$ : 95\% between independent variables (family education, family work, number of family members, early breastfeeding initiation, exclusive breastfeeding, age of weaning, giving complementary feeding, giving Vitamin A to the incidence of stunting in children age 2-5 years in Aceh Province).

Based on the results of bivariate analysis (Chisquare test), it is known that all independent variables have $p<0.25$. It can be concluded that all variables proposed as hypotheses are included in the model to predict stunting events (Table 1).

Table 1: Analysis of Bivariate Analysis (Chi-Square) Results for the Identification of Independent Variables Entered as a Stunting Event Factor Model $(n=3198)$

\begin{tabular}{|c|c|c|c|c|}
\hline \multirow[t]{2}{*}{ Independent variable } & \multicolumn{2}{|c|}{ Stunting } & \multicolumn{2}{|c|}{ Normal } \\
\hline & $\mathrm{n}$ & $\%$ & $\mathrm{n}$ & $\%$ \\
\hline \multicolumn{5}{|c|}{ Family educational head } \\
\hline Lower-upper & 1209 & 41.4 & 1714 & 58.6 \\
\hline High & 96 & 34.9 & 179 & 65.1 \\
\hline \multicolumn{5}{|l|}{ Mother education } \\
\hline Lower-upper & 1137 & 41.1 & 1565 & 57.9 \\
\hline High & 168 & 33.9 & 328 & 66.1 \\
\hline \multicolumn{5}{|l|}{ Occupation family head } \\
\hline Unemployer & 156 & 33.3 & 313 & 66.7 \\
\hline Employment & 1149 & 42.1 & 1580 & 57.9 \\
\hline \multicolumn{5}{|l|}{ Employed mother } \\
\hline Unemployee & 98 & 37.1 & 166 & 62.9 \\
\hline Employee & 1207 & 41.1 & 1727 & 58.9 \\
\hline \multicolumn{5}{|l|}{ Total family members } \\
\hline Up to 4 members & 530 & 43.4 & 690 & 56.6 \\
\hline 4 members bellow & 775 & 39.2 & 1203 & 60.8 \\
\hline \multicolumn{5}{|l|}{ IMD } \\
\hline No & 922 & 50.6 & 900 & 49.4 \\
\hline Yes & 383 & 27.8 & 993 & 72.2 \\
\hline \multicolumn{5}{|l|}{ Exclusive breastfeeding } \\
\hline No & 1235 & 52.9 & 1099 & 47.1 \\
\hline Yes & 70 & 8.1 & 794 & 91.9 \\
\hline \multicolumn{5}{|l|}{ Age of weaning } \\
\hline Worse & 544 & 54.8 & 449 & 45.2 \\
\hline Good & 761 & 34.5 & 1444 & 65.5 \\
\hline \multicolumn{5}{|c|}{ Giving complementary feeding } \\
\hline Not given & 444 & 79.9 & 112 & 20.1 \\
\hline Given & 861 & 32.6 & 1781 & 67.4 \\
\hline \multicolumn{5}{|l|}{ Vitamin A } \\
\hline No & 451 & 65.7 & 235 & 34.3 \\
\hline Yes & 854 & 34.0 & 1658 & 66.0 \\
\hline Total & 1305 & 40.8 & 1893 & 59.2 \\
\hline
\end{tabular}

\section{Parent's education level against stunting}

Based on logistic regression analysis obtained only maternal education level that affects the incidence of stunting in children aged 2-5 years, with $p=0.005$ $(p<0.05)$ with an OR value of 1.4 , mothers who have low education cause stunting by 1.4 times compared to mothers with high education in children aged $2-5$ years in Aceh Province (Table 2).

Table 2: Analysis of Logistic regression test results for the identification of variables in parent education level as a stunting event factor model

\begin{tabular}{lllll}
\hline Independent variables & $\mathrm{B}$ & $\mathrm{P}$ & $\mathrm{OR}$ & $95 \% \mathrm{Cl}$ \\
\hline Level of education of head of family & 0.102 & $0.482^{*}$ & 1.1 & $0.833-1.473$ \\
Level of mother education & 0.316 & 0.005 & 1.4 & $1.100-1.711$ \\
Constant & 0.316 & 0.000 & 1.4 & \\
\hline${ }^{*}$ Not included in the multivariate model $(p>0.25)$ & & & &
\end{tabular}

The results of bivariate analysis using simple logistic regression revealed that based on the level of 
parental education, the level of education of mothers who entered as modeling in predicting the incidence of stunting in children aged 2-5 years, with $p=0.005$. While the variable level of education of the head of the family cannot be included in the modeling, because $p>0.25$ was considered $(p=0.482)$. Hence, based on the level of parental education, only the level of maternal education allows the creation of a regression model equation, which is in the following form:

\section{$Y=0.316+(0.316)$ Mother's Education Level}

In the above model, a mathematical calculation of the probability of a child aged 2-5 years of age getting stunted is as follows:

$$
Y=\frac{1}{1+e\left(^{-0.316+0.316 \text { Mother's Education Level }}\right)}
$$

Overall, this model can predict the high or low influence of risk factors (mother's education level) in relation to the incidence of stunting of children aged 2-5 years by $59.2 \%$ (overall percentage $59.2 \%$ ).

\section{Parents' jobs against stunting}

The head of the family who is unemployed by $33.3 \%$ had to stunt children at the age of $2-5$ years, as well as the mothers who are not employed either $37.1 \%$. The family head who is employed has a significant influence on the incidence of stunting in children aged $2-5$ years, with $p=0.001$ ( $p$-value $<0.05$ ) with an OR value of 1.5 . The possibility of stunting children is 1.5 times caused by the head of the family who does not work when compared to the KK who works. Then, based on the work of the mother, apparently had no effect on the incidence of stunting ( $p=0.992)$. Parents' work also significantly influences the incidence of stunting in children aged $2-5$ years (Table 3 ).

Table 3: Analysis of Logistic regression test results for the identification of parents' work variables as a stunting event factor model

\begin{tabular}{lllll}
\hline Independent variable & $\mathrm{B}$ & $\mathrm{p}$ & $\mathrm{OR}$ & $95 \% \mathrm{Cl}$ \\
\hline Father occupation & 0.377 & 0.001 & 1.5 & $1.170-1.818$ \\
Mother occupation & 0.001 & $0.992^{*}$ & 1.0 & $0.758-1.323$ \\
Constant & 0.318 & 0.000 & 1.4 & \\
\hline${ }^{*}$ Not included in the multivariate model $(\mathrm{p}>0.25)$ & &
\end{tabular}

Based on the level of parents' work, the work of fathers who entered as modeling in predicting the incidence of stunting in children aged 2-5 years, with $p=0.001$. While the mother's occupational level, variable is not included in the modeling, because $p>0.25$ was considered ( $p=0.992$ ). Making the regression model equation for the father's occupation work variables is as follows:

$$
\mathrm{Y}=0.318+(0.377) \text { Father's occupation }
$$

In the above model, a mathematical calculation of the probability of a child aged 2-5 years of age getting stunted is as follows:

$$
\mathrm{Y}=\frac{1}{1+\mathrm{e}\left(^{-0.318+0.377 \text { Father's occupation }}\right)}
$$

The equation model obtained can predict the influence of the $\mathrm{KK}$ work factor in relation to the stunting incidence of children aged $2-5$ years by $59.2 \%$ (overall percentage $59.2 \%$ ).

\section{Number of family members for stunting}

Statistically, it turns out that the presence of the number of family members in a household influences the incidence of stunting in children aged 2-5 years, with $p=0.017(p<0.05)$ with an $O R=1.2$, so a large number of family members has the opportunity by 1.2 times causing stunting children compared to families who have few family members (Table 4).

The regression equation model for number of family work variables based on the results of the study above and the mathematical derivation of children aged 2-5 years to experience stunting is as follows:

$Y=0.246+(0.176)$ number of family members

In the above model, a mathematical calculation of the probability of a child aged $2-5$ years of age getting stunted is as follows:

$$
\left.\mathrm{Y}=\frac{1}{1+\mathrm{e}\left(^{-0.246+0.176}\right. \text { Number of Family Members }}\right)
$$

Equation models obtained can predict the influence of many factors in the number of family members in relation to the incidence of stunting of children aged $2-5$ years by $59.2 \%$ (overall percentage $59.2 \%)$.

Table 4: Analysis of Logistic regression test results for identification of the variable number of family members as a stunting event factor model

\begin{tabular}{lllll}
\hline Independent variable & $\mathrm{B}$ & $\mathrm{p}$ & $\mathrm{OR}$ & $95 \% \mathrm{Cl}$ \\
\hline Total member of family & 0.176 & 0.017 & 1.2 & $1.032-1.378$ \\
Constant & 0.246 & 0.000 & 1.3 & \\
\hline
\end{tabular}

Overall percentage $59.2 \%$

\section{IMD against stunting}

The results of bivariate analysis using simple logistic regression showed that early breastfeeding initiation affected the incidence of stunting in children aged 2-5 years, with $p=0.000(p<0.25)$, with an $\mathrm{OR}=2.7$ which the mothers who did not do the IMD process 2.7 times as likely to have stunting children compared to those who did the IMD process.

Table 5: Analysis of Logistic regression test results for identification of IMD variables as a stunting event factor model

\begin{tabular}{lllll}
\hline Independent variable & $\mathrm{B}$ & $\mathrm{P}$ & $\mathrm{OR}$ & $95 \% \mathrm{Cl}$ \\
\hline $\mathrm{IMD}$ & 0.977 & 0.000 & 2.7 & $2.287-3.084$ \\
Constant & -0.024 & 0.606 & 1.0 & \\
\hline *Overall percentage 59.9\%. & & & &
\end{tabular}


The results of the bivariate analysis using simple logistic regression (Table 5), which is based on the IMD pattern, are included as a modeling in predicting the incidence of stunting in children aged 2-5 years, with $p=0.000(p<0.25)$. Making the regression model equation is as follows:

$$
Y=-0.024+(0.977) \text { IMD }
$$

Based on the model, the probability of a child aged $2-5$ years old to experience stunting is as follows:

$$
Y=\frac{1}{1+e\left(^{0.024+0.977 I M D}\right)}
$$

The obtained equation model can predict the effect of mothers who do not carry out the IMD process in relation to the stunting incidence of children aged 2-5 years by $59.9 \%$.

\section{Exclusive breastfeeding for stunting}

Exclusive breastfeeding (breastfeeding only up to children aged 5 months 29 days) in Aceh Province based on 2015 PSG data that have been successful only reached $27.0 \%$. The current condition of children aged $2-5$ years stunting is also getting higher at $40.8 \%$. Proportionally, $52.9 \%$ of children who did not receive exclusive breastfeeding experienced acute nutritional problems (stunting). Exclusive breastfeeding is very influential on the incidence of stunting in children $(p=0.000$, with OR $=12.6)$, where children aged $2-5$ years who did not receive exclusive breastfeeding exclusively had an opportunity to experience stunting of 12.6 times compared to children who have had exclusive breastfeeding.

The results of the bivariate analysis used simple logistic regression (Table 6), to identify variables exclusive breastfeeding, known the value of $p=0.000$ so that this variable entered as modeling in predicting the incidence of stunting in children aged 2-5 years, $(p<0.25)$. Making regression model equation is as follows:

Table 6: Logistic regression test results for the identification of variables for exclusive breastfeeding as a stunting event factor model

\begin{tabular}{lllll}
\hline Variable independent & $\mathrm{B}$ & $\mathrm{p}$ & $\mathrm{OR}$ & $95 \% \mathrm{Cl}$ \\
\hline Exclusive breastfeeding & 2.545 & 0.000 & 12.6 & $9.853-16.491$ \\
Constant & -0.117 & 0.005 & 0.9 & \\
\hline${ }^{*}$ Overall percentage 63.4\%. & & & &
\end{tabular}

$$
Y=-0.117+(2.545) \text { Exclusive breastfeeding }
$$

Based on these models, the probability of a child aged 2-5 years to experience stunting is as follows:

$$
Y=\frac{1}{1+e\left(^{0.117+2.545 \text { Exclusive breastfeeding }}\right)}
$$

Equation models obtained can predict the influence of mothers who do not provide exclusive breastfeeding in connection with the incidence of stunting of children aged $2-5$ years amounted to $63.4 \%$.

\section{Age of weaning against stunting}

Inadequate weaning (under 24 months and over 24 months) by mothers proportional to $54.8 \%$, children aged 2-5 years experience stunting problems. Age weaning has a significant effect on the incidence of stunting in children aged 2-5 years in Aceh Province, with a value of $p=0.000$ and an OR value of 2.3. Bad weaning has a probability of 2.3 times stunted compared to children with good weaning.

The results of the bivariate analysis use simple logistic regression (Table 7), to identify variables weaning age, it is known that the value of $p=0,000$ so that this variable entered as deep modeling predicts the incidence of stunting in children aged 2-5 years, $(p<0.25)$. Making equations regression models and probability derivatives are as follows:

$$
Y=-0.192+(0.832) \text { Age Weaning }
$$

Based on these models, the probability of a child aged $2-5$ years to experience stunting is as follows:

$$
Y=\frac{1}{1+e\left(^{0.192+0.832 \text { Age Weaning }}\right)}
$$

Equation models obtained can predict the influence of mothers who are not well process weaning in relation to the incidence of stunting of children aged $2-5$ years of $62.2 \%$.

Table 7: Analysis of Logistic regression test results for identification of weaning age variables as factor models

\begin{tabular}{lllll}
\hline Variable independent & $\mathrm{B}$ & $\mathrm{p}$ & $\mathrm{OR}$ & $95 \% \mathrm{Cl}$ \\
\hline Age of weaning & 0.832 & 0.000 & 2.3 & $1.973-2.678$ \\
Constant & -0.192 & 0.003 & 0.8 & \\
\hline${ }^{*}$ Overall percentage $62.2 \%$. & & &
\end{tabular}

*Overall percentage $62.2 \%$

\section{stunting}

\section{Giving complementary feeding against}

Giving complementary feeding has a significant effect on the incidence of stunting in children aged 2-5 years, with $p=0.000(p<0.05)$ and has an OR value of 8.2 (Table 8). Children who do not get complementary feeding 8.2 times will experience stunting compared to children who have received complementary feeding since the age of 6-59 months.

Regression equation model for complementary feeding giving variables based on the results of the study above as well mathematical derivation that the probability of giving complementary feeding to children aged $2-5$ years for experiencing stunting is as follows: 


$$
\mathrm{Y}=-1.377+(2.104)
$$

Based on these models, the probability of a child aged 2-5 years to experience stunting is as follows:

$$
Y=\frac{1}{1+\mathrm{e}\left({ }^{1.377+2.104 \text { Provision of complementary feeding }}\right)}
$$

Provision of complementary feeding equation models that can predict the effect of giving a good MP-ASI given or not given in connection with the incidence of stunting of children aged 2-5 years amounted to $69.6 \%$ (overall percentage $69.6 \%$ ).

Table 8: Analysis of Logistic regression test results for the identification of variables for giving complementary feeding as a model

\begin{tabular}{lllll}
\hline Independent variable & $\mathrm{B}$ & $\mathrm{p}$ & $\mathrm{OR}$ & $95 \% \mathrm{Cl}$ \\
\hline Giving complementary feeding & 2.104 & 0.000 & 8.2 & $6.563-10.245$ \\
Constant & -1.377 & 0.000 & 0.3 & \\
\hline${ }^{*}$ Overall percentage 69.6\%. & & &
\end{tabular}

\section{Provision of Vitamin A against stunting}

The provision of Vitamin A capsules to children consists of blue Vitamin A capsules (at age 6-11 months) and Vitamin A is red (at 12-59 months). Proportionally child who did not get Vitamin A capsules by $65.7 \%$ had stunting. Giving capsules Vitamin A significantly influences $(p=0.000)$ on the incidence of stunting in children aged 2-5 years in Aceh Province, with an OR value of 3.7 (Tables 9 and 10). Children who do not get Vitamin A capsules have a 3.7 times chance to experience stunting compared to children who get it. The results of the bivariate analysis using logistic regression revealed that giving Vitamin A was identified as a modeling in predicting the incidence of stunting in children aged 2-5 years, with $p=0.000$ ( $p<0.25$ ).

Table 9:Analysis of Logistic regression test results for the identification of variables for providing Vitamin $A$ as a model

\begin{tabular}{lllll}
\hline Variable independent & $\mathrm{B}$ & $\mathrm{p}$ & $\mathrm{OR}$ & $95 \% \mathrm{Cl}$ \\
\hline Pemberian Vitamin A & 1.315 & 0.000 & 3.7 & $3.118-4.452$ \\
Constant & -0.652 & 0.000 & 0.5 & \\
\hline${ }^{*}$ Overall percentage 65.9\%. & & & &
\end{tabular}

Provision of Vitamin $A$ in children aged 2-5 years included in the equation model to predict the incidence of stunting. Making a regression model equation with the following form: $Y=-0.652+(1.135)$ giving Vitamin $\mathrm{A}$. In the above model, a mathematical calculation of the probability of a child aged 2-5 years to experience stunting is as follows:

$$
Y=\frac{1}{1+e\left({ }^{0.652+1.135 \text { Giving Vitamin A }}\right)}
$$

Overall, this model can predict the presence or absence of the influence of risk factors (provision of Vitamin $\mathrm{A}$ ) in relation to the incidence of stunting of children aged $2-5$ years by $65.9 \%$ (overall percentage $65.9 \%$ ).
Table 10: Analysis of Logistic regression test results for the identification of independent variables as a stunting event factor model

\begin{tabular}{lllll}
\hline Independent variable & $\mathrm{B}$ & $\mathrm{p}$ & $\mathrm{OR}$ & $95 \% \mathrm{Cl}$ \\
\hline Head of family education & 0.061 & $0.749^{*}$ & 1.1 & $0.732-1.542$ \\
Mother education & 0.138 & $0.378^{*}$ & 1.2 & $0.844-1.563$ \\
Occupation of head of family & 0.318 & 0.030 & 1.4 & $1.031-1.831$ \\
Mother occupation & 0.004 & $0.983^{*}$ & 1.0 & $0.683-1.477$ \\
Total family members & 0.164 & $0.072^{*}$ & 1.2 & $0.986-1.409$ \\
Early stunting initiative & 0.147 & $0.151^{*}$ & 1.2 & $0.948-1.417$ \\
Exclusive breastfeeding & 2.736 & 0.000 & 15.4 & $11.215-21.233$ \\
Stunting age & 0.548 & 0.000 & 1.7 & $1.434-2.087$ \\
Giving MP-ASI & 2.371 & 0.000 & 10.7 & $8.083-14.192$ \\
Giving Vitamin A & 1.238 & 0.000 & 3.5 & $2.785-4.271$ \\
Constant & -3.687 & 0.000 & 0.03 & \\
\hline
\end{tabular}

"Issued in stages (backward selection).

\section{Multivariate regression modeling}

Analysis aims to find out the most dominant independent variables that influence (family education, family work, number of family members, early breastfeeding initiation, exclusive breastfeeding, age of weaning, giving MP-ASI, and giving Vitamin A) to the dependent variable (stunting) in children aged 2-5 years in Aceh Province.

After issuing a variable with $p>0.05$ in stages that are the education variable, mother's education, mother's occupation, number of family members, and early breastfeeding initiation are obtained five variables that will be included as model candidates are KK work $(p=0.030)$, breastfeeding exclusive $(p=0.000)$, age of weaning ( $p=0.000)$, giving complementary feeding $(p=0.000)$, and giving Vitamin $A(p=0.000)$ as the results are presented in Table 11.

Table 11: Results of multiple logistic regression tests for identification of variables that will enter in stunting factor model in Aceh Province 2015

\begin{tabular}{lllll}
\hline Independent variable & $\mathrm{B}$ & $\mathrm{p}$ & $\mathrm{OR}$ & $95 \% \mathrm{Cl}$ \\
\hline Occupation of head family & 0.397 & 0.002 & 1.5 & $1.154-1.916$ \\
Giving exclusive breastfeeding & 2.816 & 0.000 & 16.7 & $12.397-22.526$ \\
Weaning age & 0.544 & 0.000 & 1.7 & $1.430-2.078$ \\
Provision MP-ASI & 2.356 & 0.000 & 10.6 & $7.962-13.978$ \\
Provision Vitamin A & 1.257 & 0.000 & 3.5 & $2.841-4.347$ \\
Constant & -3.530 & 0.000 & 0.03 & \\
\hline
\end{tabular}

In this modeling process, an interaction test between combinations of independent variables is also tested which substantially/biologically interacts. Interactions that have $p<0.05$ will be included, model. This variable will be included in the multiple logistic regression analysis models, it is shown in Table 12.

Table 12: Analysis of Final results of multiple logistic regression analysis modeling Factors of Stunting Events in Children Aged 2-5 Years in Aceh Province in 2015

\begin{tabular}{llllllll}
\hline Independent variable & $\mathrm{B}$ & $\mathrm{S} . \mathrm{E}$ & Wald & $\mathrm{df}$ & Sig. & $\operatorname{Exp}(\mathrm{B})$ & $\begin{array}{l}95 \% \mathrm{Cl} \\
\text { (lower-upper) }\end{array}$ \\
\hline $\begin{array}{l}\text { Occupation of head } \\
\text { family }\end{array}$ & 0.397 & 0.129 & 9.4 & 1 & 0.002 & 1.5 & $1.154-1.916$ \\
Giving ASI Eksklusif & 2.816 & 0.152 & 341.7 & 1 & 0.000 & 16.7 & $12.397-22.526$ \\
Weaning age & 0.544 & 0.095 & 32.6 & 1 & 0.000 & 1.7 & $1.430-2.078$ \\
Giving MP-ASI & 2.356 & 0.144 & 269.2 & 1 & 0.000 & 10.6 & $7.962-13.978$ \\
Provision Vitamin A & 1.257 & 0.109 & 134.1 & 1 & 0.000 & 3.5 & $2.841-4.347$ \\
Constant & -3.530 & 0.179 & 400.9 & 1 & 0.000 & 0.03 & \\
\hline *Overall percentage 75.0. & & & & & & &
\end{tabular}

The final result of multiple logistic regression analysis found a regression modeling for predicts stunting in children aged 2-5 years in Aceh Province. Based on Table 12, we obtain the regression model in the form of an equation as follows: 


\begin{tabular}{lcrr}
\hline & & $-3.530+0.397$ & Occupation of \\
Head family+2.816 giving ASI & Eksklusi+0.544 \\
Weaning Age+2.356 Giving & complementary \\
feeding+1.257Provision Vitamin A &
\end{tabular}

Based on the modeling equation above, a mathematical calculation is obtained about the probability of children aged $2-5$ years to experience stunting:

$$
Y=\frac{1}{1+\exp ^{-\left(\beta_{0}+\beta_{2} x_{2}+\ldots+\beta_{p} x_{p}\right)}}
$$

Overall, this model can predict the high or low influence of risk factors in relation to stunting in children aged $2-5$ years at $75.0 \%$ (overall percentage $75.0 \%$ ). The above equation, identifying stunting events can beestimated if know the value of work KK, exclusive breastfeeding, age of weaning, giving complementary feeding, as well administration of Vitamin A. Statistical tests for regression coefficients are known for all probability values which have a value below the alpha value $(\alpha=0.05)$, which is the KK work variable $(p=0.002)$, breastfeeding exclusive $(p=$ $0.000)$, weaning age $(p=0.000)$, complementary feeding $(p=0.000)$, and Vitamin A $(p=0.000)$.

So that in alpha $5 \%$, there is an effect of the linear relationship between breastfeeding exclusive with the incidence of stunting in children with an OR $=16.7$ which means children aged 2-5 years experience stunting of 16.7 times caused by mothers who do not give exclusive breastfeeding, amounting to 10.6 times due to not being given complementary feeding, amounting to 3.5 times not get Vitamin A capsules, and 1.7 times due to age of weaning that is not good, and for 1.5 times due to KK not working in Aceh Province in 2015. Through this model, with five pieces, independent predictor variable consisting of head of the family occupation, exclusive breastfeeding, age weaning, giving complementary feeding, and giving Vitamin A, can estimate the influence of factors the risk in relation to the incidence of stunting in children aged $2-5$ years is $75.0 \%$. This figure is to explain that the equation is very good to predict stunting events according to the state of the independent variables based on the results of the study after multivariate analysis was performed with a binary logistic regression statistical test that the factors were influencing the incidence of stunting is a factor: Work KK, exclusive breastfeeding, age weaning, giving complementary feeding, and giving Vitamin A. Furthermore, the most dominant factor causes the incidence of stunting in children aged 2-5 years in Aceh Province, so exclusive breastfeeding is the most dominant predictor variable. The OR value of this variable is the highest among the other variables. The greater the OR, the greater the possibility of these risk factors causing children at the age of 2-5 years to experience stunting. The OR value for this variable is already controlled by other variables, namely, administration of complementary feeding, provision of Vitamin A, age of weaning, as well head of the family occupation.

\section{Discussion}

Stunting determinants have been studied extensively both globally and nationally. Stunting is a process with an impact that can extend not only to life but also to the next generation. Malnutrition often starts in the womb, especially in children and women. Based on the results of the study, it turns out the main cause of stunting in children aged 2-5 years in the Province of Aceh which is a socioeconomic condition including maternal education $(p=0.005)$ and employment head of family $(p=0.001)$. The causative factors are not directly related to parenting such as not IMD process $(p=0.000)$ and non-exclusive breastfeeding ( $p=0.000)$, are not good administration of complementary feeding $(p=0.000)$, age of weaning $(p=$ $0.000)$, and also due to Vitamin A deficiency ( $p=0.000)$. The results of the study also found several variables that did not affect the incidence stunting, such as education of the head of the family $(p=0.482)$ and mother's occupation ( $p=0.992$ ). Related research large-scale stunting generally utilizes national survey data for Basic Health Research by the Indonesian Ministry of Health and other macrodata. Stunting in various regions in Indonesia can be influenced by various aspects such as poverty. Stunting risk factors for toddlers in various regencies/ cities in Indonesia include the gross regional domestic product per capita, level education, poverty level, hygiene behavior, and utilization [10]. The incidence of stunting in toddlers in Indonesia is influenced by father's height, maternal height, age, place of residence, socioeconomic status, mother's education, infectious diseases, personal hygiene, and environmental sanitation [11], [12]. The prevalence of stunting is significantly higher in children who are his parents have low education [13], [14]. Factors that cause it to occur malnutrition in children are the lack of access to food, parenting inappropriate, poor sanitation, and lack of health services [15]. To overcome nutritional problems, especially stunting, cross-action is needed sectoral with adequate food intake. Research in Ethiopia says that the concentration of zinc and calcium in breast milk and the quality and quantity of feeding ASI-assistants are factors that influence the incidence of stunting in children age 6-11 months [16]. Nutrition consumption, sex, nutritional status, administration status ASI, and socioeconomic status are positively correlated with the incidence of stunting in children aged 6-72 months [15]. The prevalence of stunting is quite high in many environments high prevalence of infectious diseases [17]. Primary school-aged children (6-15 years) the status of nutritional stunting has cognitive abilities, math scores, and IQ scores lower than non-stunting children [18]. The stunting incident too related to late school entrance age, grade repetition, learning achievement, and drop out of school [19]. World Bank reveals three reasons which underlie the need for interventions to reduce nutritional problems, especially stunting. First, interventions can provide high economic returns economic growth and poverty reduction. Second, nutritional interventions are 
carried out because of form and the number of worrying nutritional problems. Third, nutrition intervention is carried out because of purchasing power bad society [20].

\section{Conclusion}

Factors influence the incidence of stunting in children aged 2-5 years in the Province Aceh $(p<0.05)$. The dominant factor influencing the incidence of stunting in children aged 2-5 years in Aceh Province, namely, exclusive breastfeeding 16.7 times, 10.6 times due not given complementary feeding, by 3.5 times because they did not get Vitamin A capsules, by 1.7 times due to age of weaning that is not good, as well as 1.5 times due to father's occupation not working. Variable which no effect on the incidence of stunting was the education of the head of the family dan mother's occupation.

\section{References}

1. United Nation Development Programme. Human Development Report 2011. Sustainability and Equity: A Better Future for All. New York: United Nation Development Programme; 2011. https://doi.org/10.18356/fdcff8d6-en

2. Badan Pusat Statistik. Ketimpangan Pendidikan di Indonesia. Pemerataan Akses Pelayanan Kesehatan Menuju Indonesia Sehat. Indikator Kesejahteraan Rakyat. Jakarta: Badan Pusat Statistik; 2016. https://doi.org/10.33007/inf.v2i1.190

3. Badan Pusat Statistik. Pemerataan Akses Pelayanan Kesehatan Menuju Indonesia Sehat. Indikator Kesejahteraan Rakyat. Jakarta: Badan Pusat Statistik; 2017.

4. United Nation Children's Fund. The State of the World's Children 2014 in Number: Every Child Counts. New York: United Nations Children's Fund; 2014. https://doi.org/10.18356/8504d62b-en

5. World Health Organization. Global Nutrition Targets 2025: Stunting Policy Brief. Geneva: World Health Organization; 2014.

6. World Health Organization. Training Course on Child Growth Assessment: Interpreting Growth Indicators. Geneva: World Health Organization; 2008.

7. Kudlová E, Schneidrová D. Dietary patterns and their changes in early childhood. Cent Eur J Public Health. 2012;20(2):126-34. https://doi.org/10.21101/cejph.a3703

PMid:22966737

8. Atmarita. Nutrition problem in Indonesia. An Integrated
International Seminar and Workshop on Lifestyle. Yogyakarta: Gadja Mada University; 2005.

9. Victora CG, De Onis M, Hallal PC, Blössner M, Shrimpton R. Worldwide timing of growth faltering: Revisiting implications for interventions. Pediatrics. 2010;125(3):e473-80. https://doi. org/10.1542/peds.2009-1519

\section{PMid:20156903}

10. Ulfani DH, Martianto D, Baliwati YF. Faktor-faktor sosial ekonom dam kesehatan masyarakat kaitannya dengan masalah gizi underweight, stunted, dan wasted di Indonesia: Pendekatan ekologi gizi. J Gizi Pangan. 2011;6(1):59-65. https://doi. org/10.25182/jgp.2011.6.1.59-65

11. Aditianti F. Faktor determinan stunting pada anak usia 24-59 bulan di Indonesia. J Info Pangan Gizi. 2010;19:2. https://doi. org/10.32382/mgp.v25i1.64

12. Fentaw R, Bogale A, Abebaw D. Prevalence of child malnutrition in agro-pastoral households in Afar Regional State of Ethiopia. Nutr Res Pract. 2013;7(2):122-31. https://doi.org/10.4162/ nrp.2013.7.2.122

PMid:23610605

13. Senbanjo IO, Oshikoya KA, Odusanya OO, Njokanma OF Prevalence of and risk factors for stunting among school children and adolescents in Abeokuta, Southwest Nigeria. J Health Popul Nutr. 2011;29(4):364-70. https://doi.org/10.3329/ jhpn.v29i4.8452 PMid:21957675

14. Maleta K. Undernutrition. Malawi Med J. 2006;18(4):189-205. PMid: 27529011

15. Amare B, Moges B, Fantahun B, Tafess K, Woldeyohannes D, Yismaw G, et al. Micronutrient levels and nutritional status of school children living in Northwest Ethiopia. Nutr J. 2012;11:108. https://doi.org/10.1186/1475-2891-11-108 PMid:23237638

16. Walker SP, Chang SM, Powell CA, Simonoff E, GranthamMcGregor SM. Early childhood stunting is associated with poor psychological functioning in late adolescence and effects are reduced by psychosocial stimulation. J Nutr. 2007;137(11):24649. https://doi.org/10.1093/jn/137.11.2464 PMid: 17951486

17. De Onis M, Blössner M. The World Health Organization globa database on child growth and malnutrition: Methodology and applications. Int J Epidemiol. 2011;32:518-26. https://doi. org/10.1093/ije/dyg099

18. Brito GN, De Onis M. Growth status and academic performance in Brazilian school age children: Growth retardation impairs mathematical, but not reading and spelling abilities. Arq Neuropsiquiatr. 2006;64(4):921-5. https://doi.org/10.1590/ s0004-282x2006000600006

19. Daniels MC, Adair LS. Growth in young Filipino children predicts schooling trajectories through high school. J Nutr. 2004;134(6):1439-46. https://doi.org/10.1093/jn/134.6.1439 PMid:15173409

20. World Bank. Improving Nutrition Through Multisectoral Approaches. New York: World Bank; 2013. 